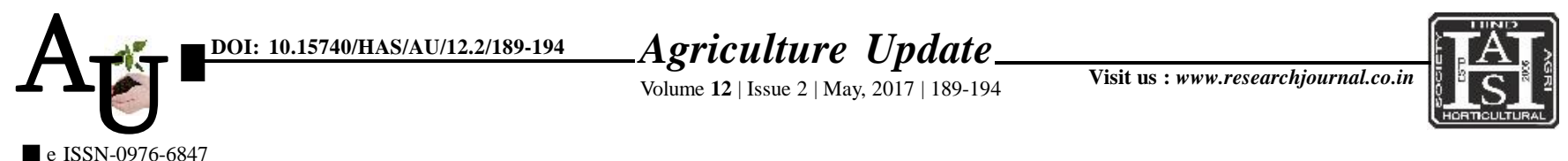

\title{
Research Article: Impact of drip irrigation system in Bikaner district of Rajasthan
}

\section{H.L. VERMA AND S.K. SHARMA}

Article Chronicle:

Received :

05.02.2017;

Revised :

24.02.2017;

Accepted :

05.03.2017

\section{KeY WoRds:}

Drip irrigation system, Cropping pattern,

Economic

development, Yield of crops
SUMMARY : Proper economization of water would be advantageous to the farmers as well as it would be helpful in bringing the more land under cultivation. In order to use such a precious natural resource economically, drip irrigation would be a possible solution which minimizes the losses of water and fertilizer as well as increase the yield of crops resulting the more profit and quality of product. The present study was conducted in four Panchayat samities (out of six) in Bikaner district of Rajasthan. From the selected four Panchayat samities, a total of 234 respondent farmers having drip irrigation system were selected randomly for the study purpose. The data were collected by personal interview method with the help of interview schedule. Collected data were classified, tabulated and statistically analyzed. The findings of the study revealed that the area under vegetable cultivation was increased. The total gross cropped area (299 ha) and cropping intensity $(20.25 \%)$ was increased. The per hectare expenditure on crop production was increased (Rs. 2999.00) after adoption of drip irrigation due to the area increased under vegetable cultivation and also fallow land utilized under such crops by the farmer. The per hectare gross income as well as net income of the farmers was increased, farmers incurred the additional expenditure (Rs. 27677.00) on education, food and clothes, house construction and maintenance, farm implements and mechanical power purchasing as well as social amenities also because of adoption of drip irrigation system. Since the farmers generated more income from their crop production, it was also observed that per hectare average yield of vegetable crops was increased significantly after the adoption of drip irrigation system which indicates the positive impact of drip irrigation system.

How to cite this article : Verma, H.L. and Sharma, S.K. (2017). Impact of drip irrigation system in Bikaner district of Rajasthan. Agric. Update, 12(2): 189-194; DOI : 10.15740/HAS/AU/12.2/189-194.
Author for correspondence :

\section{H.L. VERMA}

Directorate of Extension Education, Agriculture University, JODHPUR (RAJASTHAN) INDIA

Email:verma_571978@ rediffmail.com See end of the article for authors' affiliations 